\title{
Bartholomäus Keckermann (1572-1609). The Theology of the Reformation and the Logic
}

In a monograph devoted to Calvinist Theologian Lambert Daneau, Olivier Fatio argues with a common once tendency to regard sixteenth and seventeenth centuries continuators of the Reformation merely as epigones who petrified the spiritual surge of its initiators by 'systemising', 'rationalising' and 'objectivising' the masters' weighty discoveries concerning the Scripture. Scholars who yielded to this tendency, contrasting what was and what was not reformatorisch (and this was determined a priori, depending on the scholars' denomination), did not even bother to test, how those authors perceived the reformers and the Reformation itself, nor were they in position to make an objective assessment of their contribution to the spiritual movement in specific national contexts. ${ }^{1}$

What says Fatio about Daneau, may well be said about the author being the subject of the present paper - Bartholomäus Keckermann, one of those 'epigones' who was also quite often accused of 'rationalism'. ${ }^{2}$

1 O. Fatio, Méthode et théologie. Lambert Daneau et les débuts de la scolastique réformée, Geneva, 1976, pp. IX-XII. Fatio means both older (Weber, Ritschl) and newer (Bizer) works.

2 Cf. W. H. van Zuylen, Bartholomaeus Keckermann. Sein Leben und Wirkung, Tübingen, 1932. Zuylen quotes works of P. Althaus (Die Prinzipien der deutschen reformierten Dogmatik im Zeitalter der aristotelischen Scholastik, Leipzig, 1914) and H.E. Weber (Die philosophische Scholastik des deutschen Protestantismus im Zeitalter der Orthodoxie, Leipzig, 1907), where the alleged rationalism of the Melanchthonian trend in the Reformation is pointed out as a proof of its decline. 
A rationalistic thread is indeed found in the works of Keckermann. $\mathrm{He}$ remained, however, true to the spirit of the Reformation - as demonstrated by Muller - at the same time enriching it with new, original elements. ${ }^{3}$ Following this assessment - which is accurate, in my opinion - I would like to add a handful of comments on Keckermann's theological ideas that have been presented in his theological treatise as well as in logical works that emerged from it. In order to do this, I have to recapitulate the essential threads of Systema theologiae, before dealing with the application of certain aspects of logic in theology.

During the five decades between Consensus Tigerinus of 1549 - the document formulated by the Reformers of Geneva and Zurich, which was of a crucial significance for the promulgation of Calvinism in Germany - and the first edition of Keckermann's treatise, ${ }^{4}$ a huge effort was put by national reformatory communities into establishing of the doctrinal corpus and the rules organising religious life. Keckermann addresses all these issues when listing documents that should be seen as a basis of the 'orthodox' faith. According to his own words, he means the 'Helvetian, Gallic, English, Saxon, Palatinate, but also Augsburg confession correctly understood, and Saxon confession, as presented at the Council of Trent, through which is the Augsburg [confession] explained'. 5 The works of Keckermann came into being after decades of progress in the Reformation, doctrinal work and - inevitably - disputes, which were often as bitter as arguments with the common, Roman opponent. Actually, by

3 R. A. Muller, "Vera Philosophia cum sacra Theologia nusquampugnat': Keckermann on Philosophy, Theology and the Problem of Double Truth', The Sixteenth Century Journal, 15, 1984, 3, pp. 341-65.

4 Systema SS. Theologiae tribus libris adornatum, Hanau, 1602. All quotations here are from the second (Hanau, 1607; hereafter, Systema theologiae) of numerous editions of this work (Hanau, 1603, 1605, 1607, 1610, and 1615, Geneva, 1611, and Frankfurt, 1644). There are no significant differences between the editions preceding the posthumous one (1610). Bibliographical data as well as an extensive bibliography of Keckermann's works can be found in J. S. Freedmann, 'The Career and Writings of Bartholomew Keckermann (d. 1609)', Proceedings of the American Philosophical Society, 141, 1997, 3, pp. 305-64.

5 'Helvetica, gallica, anglica, belgica, Palatina, itemque Augustana vero sensu intellecta, Saxonica in concilio Tridentino exhibita, per quam Augustana declaratur'. Systema theologiae, p. 207. Confessio Saxonica is a document prepared by the Wittenberg reformer in 1551, to present it at the Council of Trent (cf. 'Sachsen II', in Theologische Realenzyklopädie, vol. 29, Berlin and New York, 1998, p. 569). 
mentioning a correct interpretation of Confessio Augustana, Keckermann alludes to a deep split within the Reformation, that was a result of a new interpretation of the Last Supper presented by Melanchthon in Confessio Augustana Variata in 1540. Opposing the concept of ubiquity of the resurrected body of Christ, he was inclined to the ideas of the Swiss Reformers, who accepted only a spiritual presence of Christ's body in the Eucharist.

Indeed, it was the issue of sacramental theology, that became the main source of discord between 'pure' Lutherans (or gnesio-Lutherans) and Philippists - followers of Melanchthon, who were later accused of crypto-Calvinism. A fortress of the former was at theological faculties in (alternately) Leipzig and Heidelberg, and for several years (1586-91) also in Wittenberg - which is where young Keckermann studied. His studies fell on the period following the Formula of Concord (1577), which was an attempt to reconcile the two parties - satisfactory, however, only for Lutherans. It did not prevent the conflict, with such dramatic episodes as expulsion of crypto-Calvinists from Wittenberg, a victim of which being Keckermann himself. ${ }^{6}$

Thus the 'orthodoxa fides', the defence of which the formula was intended to be, is a Reformation doctrine of the Calvinist orientation, at least when it concerns sacraments. As we will see, what Keckermann choose as his reference point was one of the essential pastoral-symbolic texts of the Reformation, that is, the Heidelberg Catechism, to the formulation of which the Silesian theologian Zacharius Ursinus made a significant contribution. ${ }^{7}$ The atmosphere of the time when Keckermann wrote his treatise can be assessed considering his answer to Catholics, who often accused the Reformers of founding numerous sects:

6 Cf. 'Philippists' and 'Gnesio-Lutherans', in The Oxford Encyclopedia of the Reformation, New York and Oxford, 1996; E. Leonard, Histoire générale du Protestantisme, vol. 2, Paris, 1982, pp. 1-30.

7 Recently, he is often regarded as the author of the work; this way, the contribution of Caspar Olevianus and other Palatine theologians is being diminished. Cf. 'Heidelberger Katechismus I', in Theologische Realenzyklopädie, vol. 14, Berlin and New York, 1985, pp. 582-86. Indeed, Keckermann himself seems to confirm this view, when mentioning 'the great Ursinis in his Catechism' (Systema theologiae, p. 2) and 'Systema suum theologicum, sive Catechesin' (ibid., p. 213, emphasis added). 
We admit and we regret that we did not succeed in achieving agreement and unanimity about every issue of the doctrine. Concerning the fundamentals [that is, the doctrine of justification through faith], however, there is an agreement. And in the most pure church, there is an agreement about the whole systematic doctrine of faith.

Further, Keckermann lists the mentioned 'orthodox' churches, including among them also the Scottish church, 'other German churches as well as Hungarian and Polish ones'. ${ }^{8}$ Therefore only the 'pure' church is truly united, and for the less pure churches, that is, other reformed brothers, the unifying factor is above all that part of the doctrine which opposes the common, Roman enemy.

Thus the historic objective of Keckermann as a theologian was to formulate a didactic treatise, which he did in a turbulent period of the concentrated assault of Counter-Reformation and futile attempts at unification within the Reformatory camp. To further complicate the situation, a new opponent appeared: the Antitrinitarians who posed a serious danger because of their religious and intellectual potential, as well as their significant influence in the region around Gdańsk, where Keckermann lived. Therefore the most straightforward - in my opinion - way to characterise the contents of Keckermann's theology is to identify his opponents and the main controversial issues. ${ }^{9}$

Thus, one should start with Antitrinitarians whom Keckermann himself granted a place of honour. It is at them, that the first of the three books making up the treatise aims. This explains, why the book begins with an elucidation of 'the nature of God' (chapter III) and 'distinguishing the persons' (chapter IV) - these are the fundamentals that would help in facing 'Samosatenians', who deny Christ the divine nature. Already the cause of Servet shocked the Genevan church, ${ }^{10}$ and the danger returned with Gentile, Biandrata, Dávid, Stankar ${ }^{11}$ and their followers, who stuck to their perfidious heresy. ${ }^{12}$ Here, it will be enough to notice that the

8 'Alias Germanicas, itemque Hungaricas et Polonicas', Systema theologiae, p. 398.

9 As a confirmation of the rightness of such approach a remark can be quoted, made by Keckermann, who wrote that, because the argument concerning the Descent of the Holy Spirit has recently 'subsided' (silet), he won't speak about it at length. For more information on this subject one should consult Bellarmino (sic!) or Beza, ibid., p. 68.

10 Ibid., p. 51.

11 Ibid., p. 351.

12 Ibid., pp. $48 \mathrm{ff}$. 
main, non-Biblical argument quoted by Keckermann to illustrate the dogma of the Holy Trinity is the thesis of modal distinction: the three divine persons are the 'modes' of existence of the same substance. ${ }^{13}$ In a similar way, various degrees of intensity of light or colour, or open and closed hand differ indeed from each other and from the essence, at the same time being with it necessarily connected. This distinction introduced by Justin and John of Damascus and accepted by Ursinus, ${ }^{14}$ becomes a logical basis which allows Antitrinitarian claims to be rejected ${ }^{15}$ (to the Biblical commentary devoted Keckermann much less attention than his opponents did), and the foundation of the true doctrine itself. Indeed, it is only to the first book of Systema theologiae that the Antitrinitarian Adam Gosławski responded, invalidating Keckermann's arguments point by point and emphasising, in Chapter VII of his work, that 'person is neither a mode nor a relation', ${ }^{16}$ but it should be seen as a substance.

As for the dispute with Roman papists, it concerns all known issues that characterise the reformatory movement from Luther onwards, and particularly the doctrines of justification and ecclesiology. As for the latter, it must be said that although contemporary Papists, like Cano or Bellarmino, use a more weighted language than their predecessors (Eck, Phigius and Hosius) did, the heart of the dispute remains unchanged, because the authority of the Pope and councils is preferred by them to the Scripture. ${ }^{17}$ Therefore, 'it is much more difficult to argue with Papists than with an Arian or a member of any other sect' because the latter acknowledge the Scripture being a necessary and sufficient point of departure for the doctrine of salvation. ${ }^{18}$ In the third part of Systema, Keckermann returned to this subject saying, that the definition of the church given by Bellarmino contradicts rules of logic. Rather than defining (as it should) the 'idea', that is, the shared essence, it narrows definiendum to 'particular circumstances, like place, time and persons'. This way, the church becomes subordinated to the Pope and Roman

13 Ibid., pp. $56 \mathrm{ff}$.

14 Ibid., p. 17.

15 Ibid., p. 95. A parallel passus can be found in Systema logicae tribus libris adornatum, Hanau, 1606 (hereafter, Systema logicae), p. 278.

16 A. Gosławski, Refutatio eorum, quae Bartholomaeus Keckermannus in libro primo systematis theologicis disputat [...], Raków, 1613 (1st ed. - 1607), p. 125.

17 Systema theologiae, pp. 171-72.

18 Ibid., pp. 171-72. 
apostolic succession. ${ }^{19}$ 'Notae', quoted by the followers of Rome as the visible qualities of the true church, are only a mystification: ${ }^{20}$ 'Catholicity' should not be understood in the quantitative and geographic sense, because the true church stands out through the purity of its doctrine; thus also in this case, the faithfulness to God's Word remains the only right criterion. ${ }^{21}$

The issue of justification is perhaps the more interesting one. Already in the first book of his treatise, when discussing God's power, Keckermann observes (as befits a good Calvinist ${ }^{22}$ ) that the grace 'does not inhere in us as a quality, but it is bestowed upon us like upon objects' ('non inhaeret nobis ut qualitas, sed exercetur circa nos tamquam obiecta'). ${ }^{23}$ In the second book, when discussing the problem of sin and accusing the Council of Trent of yielding to the Pelagian misconceptions, ${ }^{24}$ he repeats that 'the forces of will play no role in the conversion of a man, but at the first moment man and his will are passive' ('in conversione hominis nullae concurrunt vires liberi arbitrii, sed in primo momento homo et voluntas eius sese habet mere passive'). ${ }^{25}$ Only orthodox Christians avoided the danger of Pelagianism ${ }^{26}$ thanks to the doctrine of predestination, according to which God 'as the Lord and absolute Ruler has the absolute authority and right to annihilate a creature and not to come to its aid' ('habet absolutum arbitrium et ius creaturam annihilandi et non iuvandi, tamquam absolutus Dominus et Monarca'). ${ }^{27}$ In order to avoid the Scylla of Pelagianism, which was ascribed to the followers of Rome, Keckermann tried not to fall into Charybdis of theological fatalism, which he disapproves. He wouldn't be a true adept of theological, Melanchthonian humanism, caring about the human responsibility in

19 Ibid., p. 383.

20 Ibid., pp. $292 \mathrm{ff}$.

21 Ibid., p. 406.

22 Cf. C. Gallicet Calvetti, Sebastiano Castellione, il riformato umanista contro il riformatore Calvino, Milan, 1989, who emphasises the importance of the absolute will and the omnipotence of God in Calvin's works.

23 Systema theologiae, p. 117.

24 Ibid., p. 259.

25 Ibid., pp. 263-64. There is even no 'disposition' of man, who, when confronted with grace, is 'perinde ac cadaver quoddam in quo nullum est vitae principium' (ibid., p. 422).

26 Ibid., pp. 301-04.

27 Ibid., p. 309. 
salvation, if he didn't try to soften the uncompromising meaning of these statements. Thus, he elaborates that 'the remains of the divine image that are preserved after the fall' enable us to follow moral and civil virtues ${ }^{28}$ that the human will cooperates with the grace, at least 'in the course of conversion' ('in progressu conversionis'); ${ }^{29}$ that deeds alone are not enough for a man to be chosen, but they necessarily accompany the act of being chosen; ${ }^{30}$ and finally, that the predestination (which is not dual, because God predestines only to salvation, and not to damnation ${ }^{31}$ ) plays a part in the will of God, but apart from his 'omnipotence', also His justice must be emphasised, which is 'respectiva', that is, it considers the good or evil nature of the creation. ${ }^{32}$ However, how the latter (that is, the $\sin$ ) is ascribed to the human nature, is a typical crux of Calvinist theology, the solution of which Keckermann does not intend to seek. What, however, should be stressed, is his caution, and even hesitation to raise this less 'humanist' thread of Genevan theology; this, actually, matches perfectly the Heidelberg Catechism, where the doctrine of predestination is not considered at all.

It seems, however, that Keckermann was preoccupied above all with an issue that tormented the reformed churches (and particularly the German ones), concerning sacramental theology and Christology. It was, obviously, the problem of the Last Supper, to which Keckermann devoted much attention in final chapters of the second book. As already said, the problem was at the same time the most sensitive issue in the debate between adherents of different editions of Confessio Augustana. It should also be remembered that, when the theological treatise of Keckermann was being formulated, the divisions in Gdańsk itself have deepened, because the evangelical-reformed fraction (called 'Calvinist' by its opponents) grew stronger, especially among local elites. ${ }^{33}$ But what interpretation of Christ's presence in the Eucharist was presented by

28 Ibid., pp. 261-61.

29 Ibid., p. 265.

30 Ibid., p. 304.

31 Ibid., p. 296.

32 Ibid., p. 309.

33 An accurate description of that situation can be found in K. Cieślak, Między Rzymem, Wittenberga i Genewa, Wrocław, 2000, pp. 141 ff. For a more general discussion, see H.J. Cohn, 'The Territorial Princes in Germany's Second Reformation 1559-1622', in International Calvinism, ed. by M. Prestwich, Oxford, 1985, pp. 135-65. 
Keckermann to his adversaries? His approach was logical-semantic and it refers to a method taken by other Calvinist theologian and a sublime dialectician, Pietro Martire Vermigli, who had probably a significant influence on the theological orientation of Keckermann. ${ }^{34}$ One should ask, therefore, what does it mean that 'this bread is the body of Christ'? In this statement - says Keckermann - the relation between the subject and predicate is like that between a sign and what it stands for. This way, two different things become connected ('disparatum dicitur de disparato'). They merge extremely closely 'propter $a v a \lambda o \gamma ı \alpha v$ sive summam inter se convenientiam' 35 ('through a proportion, because they fit closely together'). It is, however, nothing strange or unusual ('inusitatum'); on the contrary; this kind of statement is often used when two different and independent things display a significant similarity; for example, it is said that the son 'is' his father (all over). ${ }^{36}$ Thus merged are 'duo disparata, non quod alterum sit alterum aut alterum insit alteri, sed quod alterum habeat $a v a \lambda o \gamma \iota a v$ et relationem ad alterum' (two separate things, not because one is the other or one is in the other, but because one is in certain proportion and in certain relation to the other). ${ }^{37}$ Thus the transubstantiation' (transsubstantiatio), where signatum (the body of Christ) transforms into signum (bread) is a serious misconception. ${ }^{38}$ At the same time, one should reject also the 'consubstantiation', that is, the thesis of 'local' co-existence of Christ's body with bread and His blood with wine. ${ }^{39}$ The same mistake was made by Luther himself, mainly because he had not enough time to give more thought to this. ${ }^{40}$ The relationship between the body and bread is a sacramental relation of two things that

34 Cf. Muller, op. cit.

35 Systema theologiae, p. 443.

36 Ibid., pp. 442-43.

37 Ibid., p. 444 (emphasis added).

38 Transubstantiation contravenes also the 'highest and most true' rule that sacred qualities can exist without their substance, that is, when the bread remains bread by the look, although it 'is the body of Christ' (ibid., p. 458). It is to a proper explanation of the relation between a substance and a quality, that Keckermann devoted a short treatise on metaphysics (Scientiae metaphysicae compendiosum systema, Hanau, 1609), which, therefore, is wholly subordinated to this particular theological problem.

39 To this issue Keckermann devoted several 'physical' questions in De loco et locato - one of his first published works.

40 Systema theologiae, p. 460. 
remain separated in substance. ${ }^{41}$ On the other hand, the misconception of the Lutheran ubiquitarism results from a false interpretation of 'communicatio idiomatum' between the divine and human nature of Christ. The opponents of Keckermann - in his opinion completely ignorant of logic - believe that the qualities of the divine nature, for example, the omnipresence, infect the whole person of Christ, therefore also his body becomes omnipresent in this world, and thus it may take the outer form of bread and wine, that is of the Eucharist. Keckermann's opinion, however, is that the relationship between the two natures does not result in mixing their attributes. Such belief would mean that God's power can achieve the impossible, making a body to become infinite, to abide in many places at the same time, without being attached to any particular place. All such claims are absurd and they cause ultimately the rule of contradiction to be violated; also Thomas Aquinas, 'the brightest of scholastics', regarded them as the absurdity of all absurdities. ${ }^{42}$

This - out of necessity superficial - description of those points of the doctrine over which Keckermann argues, may suffice as a synthesis of Systema theologiae, that allows this work to be correctly placed in the historical context of the religious arguments towards the end of the sixteenth century. Systema theologiae was a work intended for didactics, aimed at systematic presentation of the corpus of teachings that have been formed several decades earlier and collected in the already mentioned Heidelberg Catechism (1563). The tripartite thematic structure of Keckermann's treatise is a direct reference to the latter, as well as to the commentaries to the Catechism, written by Ursinus and his disciples. ${ }^{43}$ It should be remembered that in these works, first the issue of 'poverty' ('Erlend'), being a consequence of sin, is discussed, then that of the redemption by Christ ('Erlösung'), and finally - the human 'gratitude' ('Dankbarkeit') for Salvation, which means: deeds, liturgy, and prayers. Keckermann proposes an analogous scheme: in Book II and III of Systema, he discusses the contents of the first and second part of the Catechism, while the purely pastoral issues contained in the third part of the Catechism including into the third book, because of the systematic arrangement of

41 Ibid., p. 458.

42 Ibid., p. 110. Keckermann refers to Summa theologiae, I, q. 24, art. 3.

43 Concerning Ursinus' disciples, see, for example, Explicationes Catecheticae, Neustadt an der Haardt, 1595, edited by Ursinus' disciple, David Pareus, or Compendium doctrinae Cristianae, Geneva, 1584. 
the material. ${ }^{44}$ Thus the original contribution of the Gdańsk scholar is to be found not in theological conceptions, that he owes to his Heidelberg teachers, but rather in the systematic form to which the doctrine is subordinated. Keckermann was interested in logic since his childhood and he authored numerous works in this field. ${ }^{45}$ Thus he obviously strived to present a systematic, conforming the rules of logic argument in every field he was discussing. Indeed, his theology can be seen as an attempt at practical application of the rules presented in such works as Systema logicae. In this text, that (in my opinion) should be acknowledged as his masterpiece, he formulates - and then solves - problems that will be revisited in his theological treatise. In the latter, theological issues are discussed according to logical rules, which Keckermann accepts as the premises of theological thinking. Moreover, the 'system' of logic itself has been created with the intention of a religious dispute, as clearly evidenced by the commentaries that illustrate individual rules of logic. Almost every 'heretical' doctrine discussed above has been refuted there. Keckermann was deeply convinced that the primary source of all theological arguments is a wrong application of logic to the analysis of the Scripture. ${ }^{46}$ Systema logicae and Systema theologiae are symmetric works and one reflects the other; on one side there is a 'militant logic', on the other - theology with a clear mark of logic. Actually, both date from the same period, that is, Keckermann's stay in Heidelberg (1592-98). Therefore I would like to discuss this logical and methodological aspect at some length, because I believe that it reveals the original contribution of Keckermann into the theology of Reformation.

\section{Systema theologiae, p. 295.}

45 Systema logicae, praefatio: 'A primis adolescentiae meae annis quadam naturae propensione logicae studium prae omnibus aliis amavi et sectatus sum'. His bibliography can be found in Freedman, 'The Career...', op. cit., pp. 338 ff., and in Materiaty z dziejów logiki w Gdańsku i Toruniu od XVI do XVII wieku w zbiorach Biblioteki Gdańskiej Polskiej Akademii Nauk, ed. by J. Wołodźko-Sarosiek, Wrocław, 1988, pp. 32-40.

46 'Quae quidem omnia si ex Sacra Scriptura principiis et Sanctorum patruum explicatione adminiculo logicae fuissent intellecta, numquam accidisset quod hodie experimur magno incommodo Ecclesiae' (Systema logicae, p. 340). Cf., for example, the discussion on the Last Supper in Chapter II of the first part (ibid., pp. 113-15), which is devoted to the 'relationship', that is, a logical category according to which the Eucharist should be considered - in Keckermann's opinion. The tone of this discussion is even more polemical (almost verging on sarcasm), than that of Systema theologiae. 
As already said, the second and third book of Systema theologiae reflect the traditional order of Heidelberg catechetical texts, devoted to the so-called economy of salvation and built according to the 'fall - redemption' scheme. A novelty, compared to that scheme, is Keckermann's Book I, being a kind of introduction to a presentation of the true theology, by presenting the 'principles' of the doctrine, that is, God and the Revelation ('patefactio'). ${ }^{47}$ What induced Keckermann to adopt such arrangement for his work, why decided he to introduce this innovation? In my opinion, the answer to this question can be found in Keckermann's methodological interests, and I will try to prove this below.

First, theology won't be a true science - thus being a useless weapon in any dispute - without accepting a scientific method. According to Aristotle and his faithful hermeneutist Giacomo Zabarella, there are two methods, or 'orders': the synthetic one, characteristic of theoretical research that starts from principles and heads towards what consists of these principles, and the analytic one, applied in practical fields and recommending to head from a goal towards principles (means) that enable achieving it. ${ }^{48}$ As for theology, it is not a theoretical field at all, its ultimate goal being not cognitive ('nuda notitia'), but rather a consolation resulting from the communion with God ('fruitio Dei') ${ }^{49}$ thus its goal is an 'operational' one. Therefore theology, as a practical science, should be expounded according to the analytic order. ${ }^{50}$ Thus one should start from the goal (that is, the salvation), then the subiectum must be established (the human condition, corrupted by sins), to finally find appropriate means to achieve the goal. This conception has been formulated by Keckermann in one of his minor works on logic:

47 Systema theologiae, p. 5.

48 Cf. J. Zabarella, De methodis libri quattuor, liber de regressu, anastatic reprint, ed. by C. Vasol, Bologna, 1985, pp. 121-22, and the second book of De methodis. Keckermann's admiration for Zabarella can be inferred from numerous passages in his works. Keckermann regarded him as the most sublime contemporary hermeneutist of Aristotle's thought, and indeed, the only true master of logic. Cf., for example, Praecognitorum logicorum tractatus III, Hanau, 1606 (2nd ed.), pp. 21-23.

49 Systema theologiae, pp. 1-2. The Augustian-Scotistic tone of these phrasings is emphasised by Muller, op. cit., p. 348.

50 Systema theologiae, pp. 2, 213 and passim. 
It is a method accepted by sciences that are called active, like grammar, rhetoric, logic, ethics, law and the Holy Theology itself, the easy and convenient method of which is presented by the Heidelberg Catechism which begins with faith, or the enlivening consolation in our lifetime and after death, to pass on to the means, and there are three of them: acknowledging our misery, liberation through the redemption of the Mediator, which is gained thanks to faith, and finally gratitude [expressed] by the love of God and neighbour. ${ }^{51}$

Why, therefore, the first book begins not with a discussion on the goal, but rather on God and His Word? It is because - replies Keckermann these are, respectively, 'principium essendi' and 'principium cognoscendi' leading to that goal, thus they must be learned first, ${ }^{52}$ for it is impossible to talk about Salvation without knowing its author and the ways through which it has been revealed. In fact, to introduce this issue, Keckermann has to suspend - so to say - the analytic order and to apply the synthetic scheme. He begins, therefore, with the definition of the essence of the principle (God as a pure act and endless spirit - Chapter 2) to pass on to explaining the aspects of His existence (that is, the three divine persons - Chapter 3), His qualities (the will and the mind - Chapters 4 and 5) and His acts ad extra (Chapters 6-7). The whole argument is based, therefore, on a geometric order consisting in deduction (Keckermann refers here to 'statements') from antecedents (definitions and axioms). Thus the author begins with what is better known in itself (God is, actually, 'the first cognizable [being]', pp. 6 and 11), and less known to us, to finally reach what is closer to us. ${ }^{53}$ How should we interpret this sudden change of order, that apparently violates the principles of the method presented by Keckermann himself? Some scholars - as already said - regarded it as a 'rationalistic' element that challenges the primacy

51 'Hac methodo disponuntur omnes reliquia disciplinae, quae vocantur operatrices, ut sunt grammatica, rhetorica, logica, ethica, iurisprudentia et ipsa etiam S. Theologia, cuius methodum Analyticam expeditam certe et facilem nobis Catechesis Palatina exhibuit, incipiens a fide, vivifica nimirum consolatione in vita et morte: deinceps ad media progrediens, quae tria sunt: agnitio miseriae, liberatio facta per Mediatoris satisfactionem fide applicandam. Et denique gratitudo in dilectione Dei et proximi'. Systema logicae compendiosa methodo adornatum, Hanau, 1601, p. 147.

52 Ibid., p. 6.

53 Cf. Zabarella, op. cit., pp. 143-44. 
of the cognition of God based on the Revelation. ${ }^{54}$ According to Zuylen, for example, the 'theosophy' of the first book of Systema theologiae is the 'heart and foundation of the whole doctrine'55 of Keckermann, and a potential danger to the Bible-centric and Christocentric spirit of the Reformation. It seems, however, that there is no risk of rationalism in Keckermann's thought. The definition of the divine being, given at the very beginning of the treatise, should be regarded as what it actually is rather than as an unguarded introduction of the 'God of philosophers'. Keckermann emphasises that, in his introduction to the true theology, he does not discuss God as such (which does - or at least it believes that it does - the metaphysics), but rather he accepts Him as the supreme principle, within the limits of our comprehension ('ex captu mentis nostrae'), because it is from it that the aim and means of theology can be deduced. ${ }^{56}$ In other words, the definition of God accepted here, as well as the deduction of His personality and tripartite nature, determine only the necessary conditions of thinking about Salvation. For this to be possible, God is necessary, in three persons, and above all the Son and the Holy Spirit, as a single being. This, in turn, can be understood if God is 'the act and the spirit'. It does not mean, however, that this definition has been accepted as an absolute and exhaustive one, because it is only 'remains' of 'integra imago Dei' that we had before the fall. Keckermann adds promptly that he agrees with John of Damascus, who regarded God

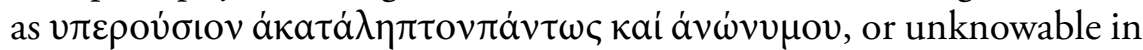
himself, as there is no higher idea that would contain Him. ${ }^{57}$

This attempt at a scientific theology has therefore also another meaning, being - in my opinion - purely tactical. I believe that Keckermann has chosen initially the deductive and synthetic procedure because - as recommended by Zabarella - it is a method that demonstrates par excellence, more perfect than the 'second-rate' analytic method, because the progression from the results to the causes (that is, analysis or 'resolutio') does not contain the necessity that is inherent in the deduction

54 Zuylen, op. cit., pp. 47-48 and 70. Zuylen's monograph is the only holistic study on Keckermann's thought, although it is focused on theology rather than on other fields. 55 Ibid., p. 21.

56 'De Deo hic [...] non agitur tamquam de subiecto contemplationis [...] sed [...] ut est principium quoddam primum et summum, a quo tum ipse finis, tum media etiam theologiae necessaria dependent'. Systema theologiae, pp. 6-7.

57 Ibid. See also Systema logicae, p. 37. God can be determined only per analogiam. 
of results from the causes ('compositio'). ${ }^{58}$ Then, Keckermann repeats that, in his deduction related to the persons, he applied the method of demonstrating 'according to the first mode of necessity' ('in primo modo necessitatis'), ${ }^{59}$ that Zabarella would regard as the principal one ('potissima'). He has chosen this method, as - considering the dialectic ability of his adversary - the best tool available in the methodology of his time was necessary to present the basics of his theology. This relationship between the choice of the method of demonstrating and the adversary is clearly visible in the first book:

Thus far we have demonstrated and at the same time presented the true and correct doctrine concerning the single being in three persons. Similarly, the fundamentals and principal rules have been deduced from the very nature of God and the strongest evidence of the Divine Word. Therefore, only the objections expressed by Antitrinitarians are to be briefly discussed. ${ }^{60}$

These objections 'can be, as a matter of fact, easily refuted basing on the very principles of the true doctrine', for, according to an indisputable rule, 'the same principles that are used to support the truth can be also applied to debunking the falsehood'. ${ }^{61}$ Then the principles of the above-mentioned modal distinguishing are presented.

Thus, the most certain way to protect the true doctrine as a whole, as well as its foundations, from the assaults of unjustified syllogisms of the heirs of Servet and Biandrata was the deduction - according to 'mos

58 Zabarella, op. cit., p. 134. On the other hand, Keckermann knew certainly an important Calvinist text, where the necessity of using a scientific method in the defence of the faith is defended, that is, the introduction to De veritate religionis Christianae by Filip Du Plessis-Mornay (Antwerp, 1583). The reference to the geometric method is there a purely rhetoric element, interpreted by Keckermann in a different way, in the spirit of the logic of Aristotle and Zabarella (cf. also, Zuylen, op. cit., pp. 74 ff., where it is regarded as the 'rationalism' attributed to Keckermann).

59 Systema theologiae, p. 90.

60 'Hactenus veram et orthodoxam doctrinam de unica essentia i tribus personis ita demonstravimus simul ac declaravimus ut fundamenta ac principia prima non aliunde petita sint, quam ex ipsa natura Dei et firmissimis verbi divini tesimoniis. Superest ut Antitrinitariorum obiectiones breviter discutiamus' (ibid., p. 74).

61 'Solvi facile possunt ex ipsis principiis verae doctrinae' (ibid.); 'Est enim certissima regula quod quibus principia veritas astruatur, iisdem principiis falsitas destruatur' (ibid., s. 75). 
geometricus' - the dogma of the threefold nature of God. Actually, a true and complete 'principium cognoscendi' of the holy theology is not to be found in philosophers' definitions, but rather in the revealed Word 'from which concluded and upon which built are all philosophical precepts' . ${ }^{62}$ As for other cognition methods, like that progressing 'ex creaturiis', are not sufficient - even if they are correct - to attain salvation, because they can reveal a God who has created and maintains the world, but not God - Redemptor and Saviour, ${ }^{63}$ being revealed only in the Scripture. ${ }^{64}$

Thus, even if there is any trace of rationalism in Keckermann's works, it should be considered as a secondary effect of an apologetic and polemic (that is, tactical) program. As not much rationalist - if rationalism is to be understood as questioning the crucial role of the Revelation - appear Keckermann's words, when he emphasises that God does not wish our faith to remain 'hidden and contained in its own ignorance, but rather to be revealed as clearly and distinctly as possible'. It is nothing else than the concept of 'fides quaerens intellectum', applied deliberately by Keckermann to allude to the great patristic (Augustine, Justin, John of Damascus, Dionysius the Areopagite - pseudo-Dionysius for Keckermann) and scholastic (Thomas in the first place, as 'acutissimus scholasticorum') tradition. ${ }^{65} \mathrm{~A}$ few words are due here on the status of natural theology in Keckermann's works. Although natural theology as such is not found in his encyclopaedia, he is far from ruling out - as we have already seen - a possibility that it exists. On the one hand he mentions in Systema theologiae 'natural' ways to find God proposed by pseudo-Dionysius (obviousness, contradiction, and causality), that is a posteriori ways, on the other hand he uses unrevealed 'theosophy' based on the a priori principle, that is, on the definition of God as a 'pure act and infinite spirit'. While in the former case we face a simple reference, in the latter there is an elaborate doctrine. Of course, the role of the

62 'Ex quo omnia praecepta theologica concluduntur et extruuntur' (ibid., p. 65).

63 Ibid.

64 Ibid., pp. 171-72.

65 '[...] id nobis incumbit, ut patefactionem hanc iuvante Spiritus Sancti gratia, attentis animis consideremus, et fidem circa mysterium hoc habere studeamus non implicitam et ignorantiae suae blandientem, sed quam fieri potest distinctam et claram' (ibid., p. 15). Keckermann's reference to the scholastic tradition (through Ursinus and, above all, Vermigli), and even more to that of Thomism, is the subject of the above-mentioned Muller's article. 
natural theology to the revealed one appears to be an 'ancillary' one, because it is intended as a mere tool to illustrate and to defend. A little, if anything, remains of the classical (and - to a certain degree) medieval concept of the rational theology being a necessary element (and climax) of the whole system of theology. ${ }^{66}$

Finally, concerning the analytic method, it can be claimed that Keckermann's theology, and the Heidelberg Cathechism being its base, are examples of its practical application, for both are aimed at 'enlivening consolation' ('vivifica consolatio') or 'communion with God that lies above all in affections' ('fruitio Dei residens potius in affectibus'). These are non-cognitive goals and one should find means that allow achieving them. Apart from this general framework, no significant influence of the analytic method is visible on the actual arrangement of the material. Much more useful are the rules for introducing topics, formulating opinions and building syllogisms, which Keckermann contained in his logic treatises. The rules formed a classical nucleus of the renaissance dialectics of humanist origin, and Keckermann borrowed them from the Melanchthonian tradition. Actually, as pointed out by Zuylen, the analytic method (that is, basically, the concept of a practical nature of theology) was successful to some degree only among Lutherans, but not among other 'reformed ones' (also J.A. Alsted, who - in many respects - may be seen as a continuator of Keckermann, decided to return to the medieval, scholastic concept of theology as a 'habitus mixtus', theoretical as well as practical one, and thus to a concept being a mixture of the analytic and synthetic methods ${ }^{67}$ ).

Nevertheless, Keckermann is aware of limitations on applying a method - any method - in theology. 'Acquaintance with the means leading to salvation' ('notitia mediorum salutis') originates rather from principles that are unique occurrences (the fall of Adam, the Incarnation, the redemptive Passion of Christ) than from inevitable conclusions that can be deduced from the nature of God, who - in turn - is not a universal being but rather an individual, free and transcendent one. The fundamental theological principles cannot be proved beginning from the nature of

66 On this, cf. J.-F. Courtine, Suarez et le système de la métaphysique, Paris, 1990.

67 Zuylen (op. cit., p. 164) quotes Armandus Polanus von Polandsdorf and Ludovicus Crocius. Concerning Alsted, cf. his Methodus sacrosanctae theologiae octo libris tradita, Hanau, 1623, pp. 50 ff., and 118 ff., where he acknowledges that different fields can go by the name of theology. 
their subject, and this is why they have been revealed to us by means of testimonium or the Revelation in the Scripture and through prophets. ${ }^{68}$ It is only in further conclusions that logic comes to the fore, with its principles that help creating a system. However, logic 'could not achieve much in these most important and foremost conclusions of the faith, that are to be apprehended first' ${ }^{69}$

This specific feature of theology has been, naturally, emphasised in Systema theologiae, when it is said that - contrary to other fields of knowledge that deal with tasks of a universal character, the subject of theology comprises historical events that are unique and exceptional. Because of this, however, theology is not second to any other science in the terms of 'dignity and effectiveness' (that is, the power of demonstrating), for it has a solid base in the form of testimonia fidei, encouraged by the Holy Spirit. ${ }^{70}$ When trying to confine the revealed theology within an quasi-Aristotelean epistemological scheme, in Systema theologiae, Keckermann worked out a particular type of syllogism, that he described as 'deictic'. Using it, one could come to necessary conclusions, although it was not 'peremptory', that is rigorously demonstrating. That syllogism 'proves' - and it proves in an inevitable way - although it does not 'demonstrate', because the intermediary terms it uses are deictic, that is, singular. ${ }^{71}$ Rather than a contravention, it is a supplement to the rules of Zabarellian doctrine, aimed at securing the specificity of theology as a knowledge based on revelation and the Scripture.

Regardless of whether the attempt to situate the Reformation theology within the methodological structures of Aristotelean origin is a little constrained or not, it reveals aspirations typical of the period of powerful expansion of the scholastic system, as well as needs of the religious argument from the second half of the sixteenth century onwards. ${ }^{72}$ In such situation, Keckermann set himself apparently the task to carry

68 Praecognitorum philosophorum libri duo, Hanau, 1608, pp. 121-22.

69 '[...] quae in istis summis et primis fidei conclusionibus primo apprehendendis non multum poterat', ibid., p. 124-25.

70 Systema theologiae, p. 311.

71 Systema logicae, pp. 512-26, esp. p. 523.

72 For a brief overview of these problems, see J.S. Freedman, 'Philosophy Instruction within the Institutional Framework of Central European Schools and Universities during the Reformation Era', History of Universities, 5, 1985, pp. 117-66; idem, Deutsche Schulphilosophie im Reformationszeitalter (1500-1650), Münster, 1984. 
out this operation within the framework of Aristotelean tradition, that is by repelling the assault - originating from the Calvinist camp - of a definitely different and rather aggressive so far methodological stand, that is, that of Petrus Ramus and his school. Keckermann - contrary to what Alsted and the Herborn teachers did a few years later - deemed it impossible to bring together Ramism and Aristoteleism, and to renounce the latter would result in a failure of the plan, the great tradition of Ancient philosophy, patristics and medieval scholastics to be intercepted by the Reformation. If this happened, the Reformation could no more act, with a hint of Catholicism, as the 'reborn' true faith, temporarily corrupted by followers of Rome. Without Aristotle, the culture of the Reformation would appear to be a novelty, rootless and unconnected to any tradition. Although, with passing of time, Ramus has moderated his anti-Aristoteleism, Keckermann harbours no illusions about conformity of his 'methodus unica' to the peripatetic doctrine of the knowledge. The confrontation with Ramus explains - in my opinion - some aspects of the method applied by Keckermann to theology.

Above all, the fact that Keckermann repeatedly refers to a 'method' is a concession to Ramism being in vogue at that time. According to Aristotelean terminology, the 'method' used by Keckermann in theology and other fields should be rather described as 'ordo'. A method, as taught by Zabarella, proceeds from what is known to what remains unknown, ${ }^{73}$ thus it can be used for 'finding' knowledge. Keckermann did not need that, but rather he wanted to present, in a way that would be coherent and simple from the didactic point of view, the knowledge that was already acquired or even formulated in canonical texts of the Evangelical-Calvinist theology. In such cases, Zabarella speaks of 'ordo' ${ }^{74}$ and if Keckermann decided to use the term 'methodus', it means - in my opinion - that he adopted the terminology of Ramus and his school, ${ }^{75}$ emphasising at the same time that the Aristotelean logic meets the standards of teaching, that is the field in which Ramism tried to secure its position. The originality

73 Zabarella, op. cit., p. 93.

74 Ibid.

75 Actually, in his main logic treatise, Keckermann justified this terminological misuse, differentiating between an inference of any type (methodus illativa) and a method understood as a 'complete lecture on various logical tools', that is, the order that can be applied to teaching (Systema logicae, p. 583). 
of the former resulted - according to numerous scholars ${ }^{76}$ - not from its influence on a progress in science and new discoveries, but rather from its ability to indicate an efficient way of acquiring and application of knowledge. Keckermann proves that also in this respect, without renouncing its innovative contribution, Aristoteleism works, and thus the response to the challenge of Ramus' 'methodus unica' is to be found in complexities of Zabarellian logic.

There is one more aspect that defines the form of Keckermann's theology, at the same time referring to his anti-Ramism. It should be said that in the core of Ramus' method, there was what Ramus himself termed 'lex iustitiae' that requires statements concerning any field of knowledge to be 'coherent'. Thus, statements originating from different fields must not be mixed together, and the subject and predicate in a single statement cannot belong to different fields. ${ }^{77}$ When discussing this fundamental principle of Ramism in his Systema logicae, ${ }^{78}$ Keckermann reminds that it originates from Aristotelean Prior Analytics. Then he adds that it is generally acceptable, to discuss a problem in physics in terms of logic, an ethical problem in terms of mathematics or a physical issue in terms of ethics. ${ }^{79}$ However, after having admitted this, he condemns those who apply the principle blindly, also to commentaries and digressions that are aimed at illustrating fundamentals of individual fields of knowledge. Significantly, he quotes the example of theology:

In theology, however, it is often acceptable to use, as an explanation, philosophical notions instead of commentaries; nobody would be able to convey to his disciples the complete doctrine of sacraments without using logical principles concerning the nature of relations; this, however, would not violate the principle of coherence. ${ }^{80}$

76 Cf., for example, G. Oldrini, La disputa del metodo nel Rinascimento, Florence, 1997.

77 Cf. the first part of the above-mentioned work of Oldrini.

78 'Severa methodi lex esto, ne quid in logicum physicum, in mathematicis ethicum, in ethicis physicum tractetur'. Systema logicae, pp. 587-89.

79 Ibid., p. 588.

80 'Ita saepe in theologia usu venit ut ex Philosophia aliquid pro necessaria explicatione sit adducendum in commentarii vicem; nemo enim auditoribus solide doctrinam de Sacramentis tradiderit nisi aliquid e logicis repetat de relationum natura, nec tamen idcirco legem omogeneias, violaris' (ibid.). Besides, the same subject can be discussed from different points of view (which they also disapprove); for example, a human can 
In short, using philosophy (which was understood by Keckermann mainly as logic) in theology is not only justified, but necessary. Without basic logical notions, categories and predicatives (predicamenta and predicabilia), it is impossible to formulate fundamental theses of religious apologetics, such as 'the Person is a manner of existence of the divine being' or 'the mind and the will are qualities of God'. I mean that the references to the correctness of 'mixed conclusions' ('conclusiones mixtae'), which are found frequently in Keckermann's works, are not always intended as a defence of natural rationalism and philosophy from adversaries who, most probably, posed no real danger in the scholastic world of Keckermann. How otherwise could have polemicists and preachers of the counter-Reformation era been educated in theology, without a logical and philosophical base? And since philosophy, when correctly understood, does not contradict theological truths, but is necessary to defend them, ${ }^{81}$ the danger apparently meant by Keckermann is not an irrational departure lurking in extreme factions of Lutheranism, but rather the popularity of certain applications of the Ramistic logic. These applications - under a pretence of methodological strictness, and at the same time ignoring the real structure of knowledge, that is provided only by Aristotelean logic - actually prevented theology from achieving the status of a science.

Also critics of Keckermann representing the Lutheran scholastics had no doubts about the application of logic in theology. For example, Jonas Hocher from Tübingen accused 'Calvinists', and Keckermann in particular, of preferring Agar the servant (that is, logic) to Sarah (theology). ${ }^{82} \mathrm{At}$ the same time, he did not fail to praise his Systema logicae (even a devil tells occasionally a truth ${ }^{83}$ ) and logic in general: Hocher's reservations concern only its wrong application. According to him, Keckermann

be understood as an inherent being within physics or as the object of Salvation within theology, etc. (ibid., p. 589).

81 Which has been argued in Praecognita philosophia. Cf. Muller, op. cit., pp. 350 ff. He notes that adherents of the 'double truth', Italian Aristoteleans and extreme Lutheran factions were strangely unanimous in rejecting that thesis.

82 Sylloge utilissimorum quorundam articulorum, quorum nonnulli inter Augustanae Confessioni theologos et pontifices, quidam vero inter nos et Bartholomaeum Keckermannum Dantiscanum philosophum aliosque in calvinianos summopere controvertuntur, Tübingen, 1608, 'epistola dedicatoria' p. 3v, and pp. 32-38.

83 Ibid., p. 33. 
failed to notice that philosophers are dealing with a new reality that was unknown to Aristotle, because a new idea has been revealed by God to the world: the hypostatic unity of Persons. ${ }^{84}$ Logic should be aimed at explaining this novum, and thus its basic categories (such as 'completeness' or 'qualities') must be formulated anew. ${ }^{85}$ And similarly, a Lutheran theologian Jakob Martini, who authored a work polemical against Ramus' ideas, accused Calvinists in the name of a reformed Aristoteleism ${ }^{86}$ of having no adequate knowledge of predicates to express the doctrine of consubstantiation. Because they regard the 'est' in 'hic panis est corpus meus' as the expression of a trivial metaphorical relation. ${ }^{87}$

\section{Translated by Kamil O. Kuraszkiewicz}

First published as: 'Bartłomiej Keckermann (1572-1609): teologia reformacji i logika', Odrodzenie i Reformacja w Polsce, 45, 2001, pp. 99-115.

84 Ibid., p. 50. Cf. Isaiah 31.22.

85 Ibid., pp. 51 and 67.50.

86 J. Martini, Discussionum ramisticarum libri duo, Wittenberg, 1623.

87 Idem, Partitiones theologicae quadraginta, Wittenberg, 1612, disp. XXIV. For the denial of the modal theory of Keckermann, cf. disp. I, pp. 31 ff. As said, it was 'analogy' that Keckermann referred to. 